\title{
A Principal Source of Deposited Lipid in Phosphorus Deficient Red Sea Bream*1
}

\author{
Syuichi SAKAMOTO and Yasuo Yone*2 \\ (Received April 23, 1980)
}

\begin{abstract}
To clarify a principal source of deposited lipid in phosphorus deficient red sea bream, Chrysophrys major, the effect of dietary phosphorus level on the absorption of dietary lipid and the effects of dietary carbohydrate and lipid levels on lipid content of the carcass were examined.

The absorption of dietary lipid showed a similarly high value in all groups without regard to dietary phosphorus level. Phosphorus deficient fish on diets with and without carbohydrates, stored lipid abundantly, but those on diets lacking lipid did not. Furthermore, fatty acid composition of deposited lipid in the adipose tissue was similar to that of dietary lipid.

From these findings, it was presumed that dietary lipid was not well utilized as energy source and gradually accumulated in phosphorus deficient fish.
\end{abstract}

When the experimental animals are maintained in optimum nutritional condition, body lipid levels are generally in the low level. However, in the previous study with red sea bream ${ }^{1}$, it was shown that low dietary phosphorus levels, i.e. less than $680 \mathrm{mg} / 100 \mathrm{~g}$ diet resulted in increased lipid content in the dorsal muscle, liver, and vertebrae.

This study was conducted to find a principal source of lipid deposited in phosphorus deficient fish.

\section{Experimental}

Two experiments were carried out. The effect of dietary phosphorus level on the absorption of dietary lipid was examined in the experiment $I$, and the origin of deposited lipid in the experiment II.

\section{Experiment I}

The absorption of dietary lipid was measured by use of the chromic oxide indicator technique ${ }^{2)}$. As shown in Table 1, in addition to four test diets containing various phosphorus levels $(194,340$, 680 , and $1360 \mathrm{mg} / 100 \mathrm{~g}$ diet), the lipid-free diet was prepared by replacing pollack liver oil with $\alpha$-cellulose flour, to know the amount of endogenous lipid. Phosphorus level of the lipid-free diet was adjusted at a $680 \mathrm{mg} / 100 \mathrm{~g}$ diet. Chromic oxide was supplemented to all diets at a $1 \%$ level.
The procedure of diet preparation was as described in the previous paper" ${ }^{\text {s }}$.

Red sea bream of approximate $50 \mathrm{~g}$ weight were randomly divided into ten lots of 20 fish per $150 l$ aquarium, which was continuously supplied with aerated sea water $\left(28 \pm 1^{\circ} \mathrm{C}\right)$ at a rate of $2.5 l$ per min. Each test diet was fed to duplicate lots for two weeks. After a week prefeeding period, feces were collected daily throughout the duration of the test period. Feces were siphoned out on filter paper from the water just after voiding by fish and stored at $-20^{\circ} \mathrm{C}$ until chemical analysis.

Feed and feces were chemically analyzed for $\mathrm{Cr}_{2} \mathrm{O}_{3}$ and lipid. Chromic oxide was measured by wet-nitric and perchloric acid digestion ${ }^{2)}$, and lipid by ethyl ether extraction ${ }^{4}$, respectively.

The following equation was used to calculate the net percent absorption of dietary lipid:

Net absorption $(\%)$

$$
=100 \times\left(1-\frac{F_{1}}{F_{2}}-\frac{F_{1}^{\prime} \times D_{2}{ }^{\prime}}{F_{2}^{\prime} \times D_{2}} / \frac{D_{1}}{D_{2}}\right)
$$

$\mathrm{D}_{1}$, lipid in test diet $(\%) ; \mathrm{D}_{2}, \mathrm{Cr}_{2} \mathrm{O}_{3}$ in test diet $(\%)$; $\mathrm{D}_{2}{ }^{\prime}, \mathrm{Cr}_{2} \mathrm{O}_{3}$ in lipid-free diet $(\%) ; \mathrm{F}_{1}$, lipid in feces when test diet was fed $(\%) ; \mathrm{F}_{2}, \mathrm{Cr}_{2} \mathrm{O}_{3}$ in feces when test diet was fed $(\%) ; \mathrm{F}_{1}^{\prime}$, lipid in feces when lipid-free diet was fed $(\%) ; \mathrm{F}_{2}^{\prime}, \mathrm{Cr}_{2} \mathrm{O}_{3}$ in feces when lipid-free diet was fed $(\%)$.

\section{Experiment II}

As shown in Table 2, a control diet with phos-

*1 Contribution from Fish. Res. Lab., Kyushu Univ., No. 137. This work was supported in part by a Grant-in-Aid for Scientific Research from the Ministry of Education of Japan (Grant No. 256151).

*2 Fish. Res. Lab., Kyushu Univ., Tsuyazaki, Fukuoka 811-33, Japan（酒本秀一・米 康夫：九州大学 農学部附属水産春験所). 
Table 1. Composition of test diets for experiment I

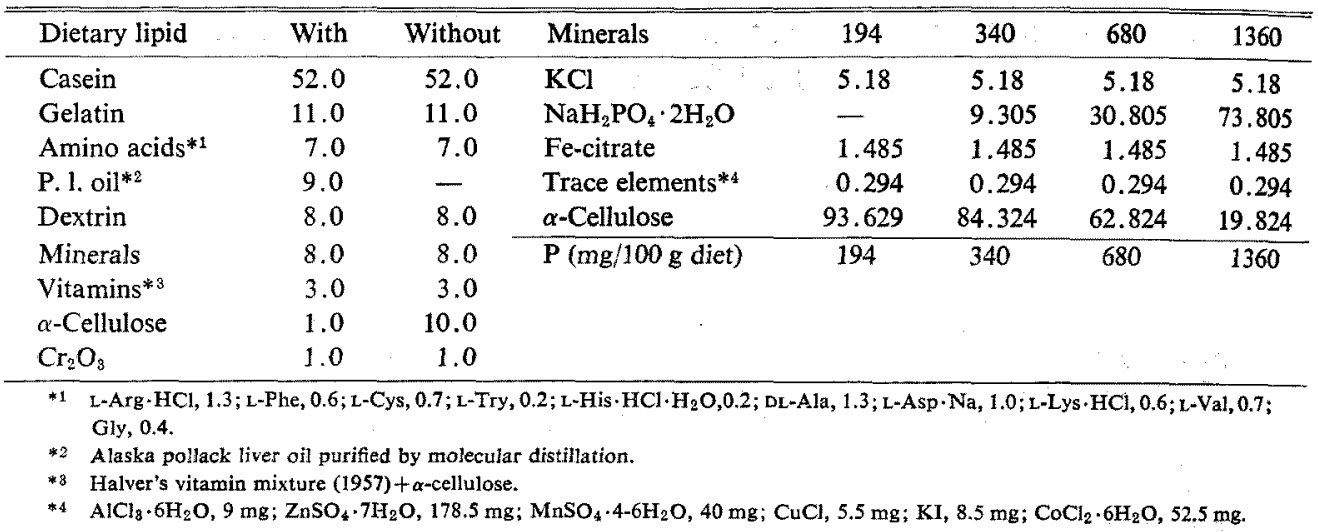

Table 2. Composition of test diets for experiment II

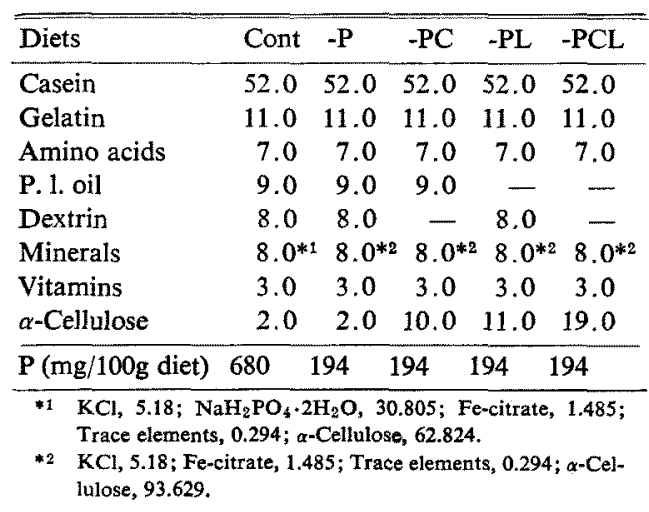

phorus supplementation (Cont) and four phosphorus deficient diets with and without lipid or carbohydrate (-P, - PC, -PL, -PCL) were employed to confirm the origin of deposited lipid. A protein-free diet was not prepared, as red sea bream does not take the diet. Twenty fish were fed on each diet for a 100 day period. The preparation of diet, fish care, and feeding were the same as described previously ${ }^{3)}$. At the termination of the feeding trial, ten fish from each group were randomly sampled and the relative organ weight (i.e. $100 \times$ liver weight/fish weight) was determined. Chemical analysis of blood serum, dorsal muscle, liver, intestine with adipose tissue, and vertebrae were subsequently carried out. Total lipid in the dorsal muscle, liver and intestine with adipose tissue were extracted by the method of Folch et al ${ }^{\mathrm{b})}$, using chloroform-methanol $(2: 1)$ mixture. Liver lipid was fractionated into polar and non-polar lipid with silicic acid chromatography $^{\mathrm{g}}$. Furthermore, deposited lipid in the adipose tissue (mesentery) was extracted and esterified with boron-trifuoride in anhydrous methanol'). These methyl esters were routinely analyzed by gas-liquid chromatography (JEOL Model $20 \mathrm{KFP}$ equiped with hydrogen flame ionization detector) on a $3 \mathrm{~m} \times 3 \mathrm{~mm}$ i.d. stainless steel column containing $10 \%$ DEGS on chromosorb W (AW) at $185^{\circ} \mathrm{C}$. Nitrogen was used as carrier gas and the flow rate was maintained at $45 \mathrm{~m} / / \mathrm{min}$. Fatty acids were identified by the method of ACKMAN and BURGHER ${ }^{8)}$ and the equivalent chain value ${ }^{\natural)}$. Quantitative fatty acid data was calculated directly as area per cent by triangulation method.

The analytical methods of other components were described in the previous paper ${ }^{10,11)}$. Student's t-test was employed at a $\mathbf{P}<0.05$ level to determine whether a significant difference existed between dietary groups.

\section{Results and Discussion}

\section{Experiment I}

As shown in Table 3, the phosphorus level of the diet had no effect on the uptake of dietary

Table 3. Effect of the dietary phosphorus level ( $\mathrm{mg} / 100 \mathrm{~g}$ diet) on lipid absorption in red sea bream

\begin{tabular}{lllll}
\hline \hline Dietary P level & 194 & 340 & 680 & 1360 \\
\hline Absorption (\%) & 98.1 & 98.7 & 98.8 & 98.4 \\
\hline
\end{tabular}

lipid, which was almost completely absorbed in all groups. Therefore, it can be concluded that lipid absorption is not related to the abnormal lipid deposition observed in phosphorus deficient fish. 
Experiment II

As shown in Table 4, the growth rate, feed efficiency, condition factor, relative liver weight (hepatosomatic index) and relative intestine weight of the groups fed the lipid-free diet without phosphorus supplementation (-PL and -PCL) were ex- tremely low when compared to those of other groups. In addition, deposited lipid was scarcely observed in the abdominal cavity in the lipid-free diet groups. No significant difference existed in condition factor or hepatosomatic index between the control group (Cont) and the phosphorus de-

Table 4. Effect of the dietary carbohydrate and lipid on growth rate, feed efficiency, condition factor, and relative organ weight of phosphorus deficient red sea bream

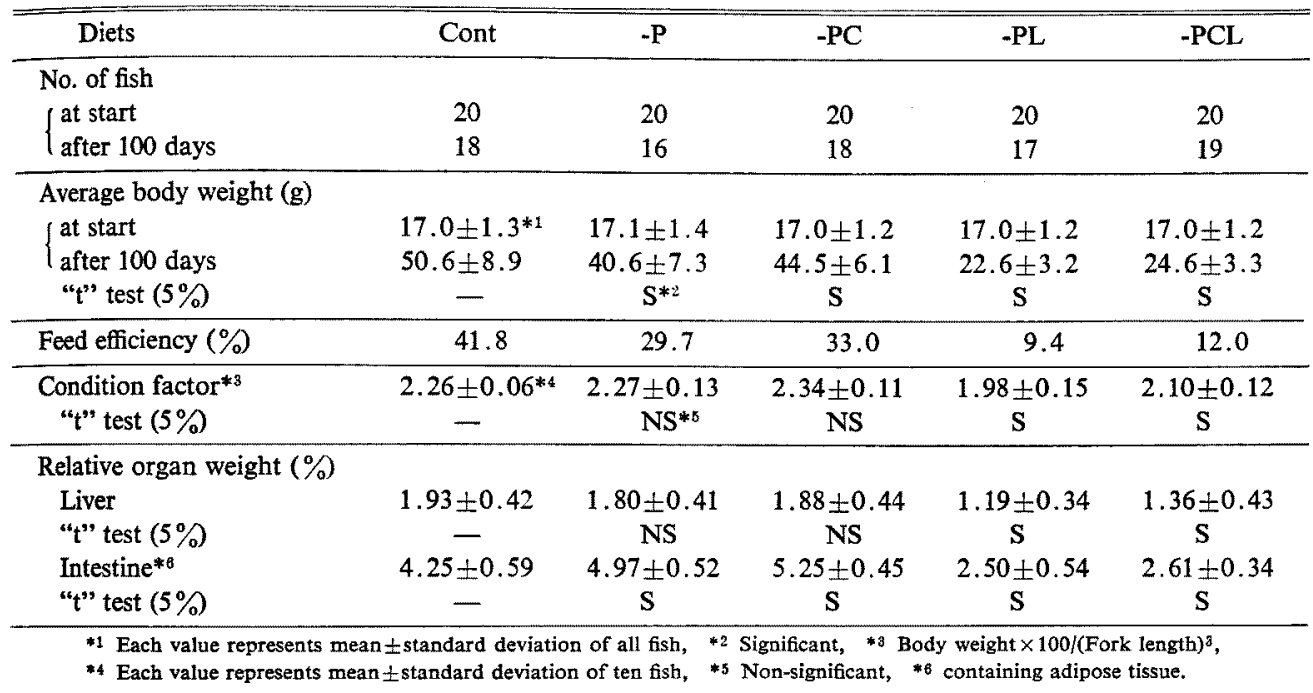

Table 5. Effect of the dietary carbohydrate and lipid on the lipid contents of dorsal muscle, liver, intestine with adipose tissue, vertebrae, and blood serum of phosphorus deficient red sea bream

\begin{tabular}{|c|c|c|c|c|c|}
\hline Diets & Cont & $-\mathbf{P}$ & $-\mathrm{PC}$ & $-\mathrm{PL}$ & $-\mathrm{PCL}$ \\
\hline \multicolumn{6}{|l|}{ Dorsal muscle } \\
\hline Moisture $(\%)$ & 75.2 & 75.6 & 74.9 & 81.2 & 81.5 \\
\hline Lipid $(\% \mathrm{db})^{* 1}$ & 3.4 & 4.1 & 5.2 & 2.6 & 3.1 \\
\hline \multicolumn{6}{|l|}{ Liver } \\
\hline Moisture $(\%)$ & 68.9 & 67.7 & 63.8 & 76.3 & 71.1 \\
\hline Lipid $(\% \mathrm{db})$ & 36.2 & 43.5 & 47.2 & 36.6 & 51.3 \\
\hline$(\mathrm{g} / 100 \mathrm{~g} \mathrm{BWt})$ & 0.22 & 0.26 & 0.36 & 0.10 & 0.20 \\
\hline NP-lipid $* 2(\mathrm{~g}) / 100 \mathrm{~g}$ protein & 68.7 & 136.4 & 144.6 & - & - \\
\hline P-lipid*3 $(\mathrm{g}) / 100$ g protein & 10.6 & 11.9 & 11.3 & - & - \\
\hline NP-lipid/P-lipid ratio & 6.5 & 11.5 & 12.8 & - & - \\
\hline \multicolumn{6}{|l|}{ Intestine } \\
\hline Moisture (\%) & 48.7 & 45.9 & 46.1 & 81.0 & 81.7 \\
\hline Lipid $(\% \mathrm{db})$ & 77.9 & 80.7 & 82.0 & 14.2 & 15.8 \\
\hline$(\mathrm{g} / 100 \mathrm{~g} \mathrm{BWt})$ & 1.70 & 2.17 & 2.32 & 0.07 & 0.08 \\
\hline \multicolumn{6}{|l|}{ Vertebrae } \\
\hline Lipid (\%db) & 20.4 & 26.7 & 27.1 & 8.9 & 10.2 \\
\hline \multicolumn{6}{|l|}{ Blood serum } \\
\hline Total cholesterol $(\mathrm{mg} / 100 \mathrm{~m} l)$ & 219 & 207 & 244 & - & 78 \\
\hline Triglyceride $(\mathrm{mg} / 100 \mathrm{~m} /)$ & 319 & 161 & 237 & 47 & 40 \\
\hline Phospholipid $(\mathrm{mg} / 100 \mathrm{~m} l)$ & 549 & 469 & 621 & 180 & 192 \\
\hline $\operatorname{NEFA}^{* 4}(\mathrm{meq} / l)$ & 0.08 & 0.08 & 0.07 & - & - \\
\hline
\end{tabular}

*1 \% on a dry weight basis, *2 Non-polar lipid, *8 Polar lipid, *4 Non-esterified fatty acids. 
ficient groups with and without dextrin supplementation (-P and -PC). However, the -P and -PC groups exhibited lower growth, feed efficiency, and higher relative intestine (with adipose tissue) weight than the control group.

Lipid content of dorsal muscle, liver, intestine with adipose tissue, and vertebrae in the -P and -PC groups were also greater than those of control group (Table 5). Furthermore, the -PC group fed dextrin-free diet had higher lipid levels in all tissues examined than those of the $-P$ group with dextrin supplementation. From these findings, it is evident that the deposited lipid in phosphorus deficient red sea bream was not derived from dietary carbohydrate. Deposited lipid was most abundant in the liver with the exception of adipose tissue and classified into non-polar group by the activated silicic acid chromatography. Increased liver lipid levels were not due to increased fatty acid inflow from the adipose tissue, as no significant difference was recognized in the blood serum level of nonesterified fatty acids (NEFA) among the control, $-P$, and -PC groups. From the lower serum tri-

Table 6. Fatty acid composition of pollack liver oil and lipid in adipose tissue of red sea bream fed phosphorus deficient diets with and without carbohydrate supplementation

\begin{tabular}{lrrrr}
\hline & P.1. oil & \multicolumn{1}{c}{ Cont } & \multicolumn{1}{c}{-P } & \multicolumn{1}{c}{ PC } \\
\hline $12: 0$ & 0.4 & & & \\
$13: 0$ & 0.1 & & & \\
$14: 0$ & 5.9 & 6.4 & 6.2 & 6.3 \\
$15: 0$ & 0.5 & 0.4 & 0.5 & 0.4 \\
$16: 0$ & 11.5 & 16.4 & 16.0 & 16.3 \\
$16: 1 \omega 7$ & 7.6 & 8.7 & 8.5 & 8.9 \\
$18: 0$ & 2.1 & 5.6 & 5.3 & 5.5 \\
$18: 1 \omega 9$ & 13.3 & 23.9 & 24.7 & 23.8 \\
$18: 2 \omega 6$ & 1.2 & 1.8 & 1.7 & 2.0 \\
$18: 3 \omega 6$ & 0.5 & & & \\
$18: 3 \omega 3$ & tr & & & \\
$20: 1 \omega 9$ & 20.1 & 15.5 & 15.6 & 15.5 \\
$20: 2 \omega 9$ & 0.5 & 0.9 & 0.9 & 0.8 \\
$20: 3 \omega 9$ & tr & & & \\
$20: 3 \omega 6$ & 0.5 & & & \\
$22: 1$ & 15.6 & 8.3 & 8.5 & 8.4 \\
$20: 5 \omega 3$ & 10.9 & 4.9 & 4.7 & 4.7 \\
$22: 4 \omega 6$ & 0.6 & & & \\
$22: 5 \omega 3$ & 1.3 & 2.2 & 2.3 & 2.2 \\
$22: 6 \omega 3$ & 4.3 & 2.8 & 2.7 & 2.7 \\
\hline
\end{tabular}

glyceride level of -P and -PC groups than that of control group, it can be concluded that lipoprotein synthesis in the liver and/or lipoprotein release from the liver may be reduced by phosphorus deficiency. Consequently, higher lipid deposition in the liver might be due in part to larger lipid inflow than outflow.

The fatty acid composition of deposited lipid in adipose tissue showed little difference among control, -P, and -PC groups, as shown in Table 6. Furthermore, the fatty acid composition was very similar to that of dietary lipid (pollack liver oil). Since lipid in the adipose tissue was mostly nonpolar, it is natural that long chain fatty acids (more than 20 carbon atoms) in these deposited lipid were slightly less than in pollack liver oil. These data show that dietary lipid was directly stored without further metabolism in phosphorus deficient fish.

From the results of this study, it was presumed that dietary lipid was not well utilized as energy source in a phosphorus deficiency state and gradually accumulated in the fish.

\section{References}

1) S. SAKamoto and Y. Yone: Bull, Japan. Soc. Sci. Fish., 44, 227-229 (1978).

2) A. Furukawa and H. Tsukahara: Bull. Japan. Soc. Sci. Fish., 32, 502-506 (1966).

3) S. SAKAmOto and Y. Yone: Bull. Japan. Soc. Sci. Fish., 39, 343-348 (1973).

4) KING: in "Micro-Analysis in Medical Biochemistry, 3rd ed." 1956, p. 131 (cited from "Rinsho Kensaho Teiyo, 26th ed." (ed. by I. KanaI and M. KANAI), Kinbara-shuppan, Tokyo, 1973, pp. IV. 12-13).

5) J. FolCh, M. LeE, and G. H. S. StANLEY: $J$. Biol. Chem., 226, 497-509 (1957).

6) D. J. Lee, J. N. Roenm, T. C. YU, and R. O. SEINNHUBER: $J$. Nutr., 92, 93-98 (1967).

7) W. R. MORRISON and L. M. SMrth: J. Lipid. Res., 5, 600-608 (1964).

8) R. G. ACKman and R. D. Burgher: J. Chromat., 11, 185-194 (1963).

9) H. H. HofstetTeR, N. Sen, and R. T. Holman: J. Amer. Oil Chem. Soc., 42, 537-540 (1965).

10) S. SaKamoto and Y. Yone: Bull. Japan. Soc. Sci. Fish., 45, 57-60 (1979).

11) S. SAKamoto and Y. Yone: Bull. Japan. Soc. Sci. Fish., 45, 231-235 (1979). 